\title{
UV Spectrophotometric Method for Estimation of Ofloxacin in Tablet Dosage Form and Comparative Study of its Two Brands
}

\author{
Safila Naveed ${ }^{1 \star}$, Tanweer Alam ${ }^{1,2}$, Asra Hameed $^{1}$ and Neelam Sharif ${ }^{1}$
}

${ }^{1}$ Jinnah University for Women, 5C, Nazimabad, Karachi, Pakistan

${ }^{2}$ Central Drug Laboratory, Drug Regulatory Authority of Pakistan, 4-B, SMCHS, Karachi, Pakistan

\begin{abstract}
Ofloxacin is used to treat a bacterial infection. It is indicated for the treatment of adults with mild to moderate infections triggered by susceptible strains of the nominated microorganisms in the infections likes acute bacterial exacerbations of chronic bronchitis, community acquired pneumonia, uncomplicated skin and skin structure infections, acute, uncomplicated urethral and cervical gonorrhea, nongonococcal urethiritis and cervicitis, mixed infections of the urethra and cervix, acute pelvic inflammatory disease (including severe infection), uncomplicated cystitis, complicated urinary tract infections and prostatitis. The most common side-effects are feeling sick, diarrhea, feeling dizzy and headache. Spectrophotometry is regarded as by its speed and simplicity, accuracy and inexpensive instrument needed, and hence it is a significant substitute to further analytical methods, through clear advantages in terms of cost of analysis. Assay of Ofloxacin tablets is carried out by a rapid, simple, accurate, and economical least time consuming spectrophotometric method and then compares it with the assay of two different brands available in Karachi, Pakistan. Results of assay reveal that both trademarks of Ofloxacin are bioequivalent and are within the endorsed range. Brand $A$ shows a percent assay of $100 \%$ while Brand $B$ shows low value for percentage assay that is $96.31 \%$.
\end{abstract}

Keywords: Ofloxacin; Infections; Susceptible strains; Spectrophotometric; Assay

\section{Introduction}

Fluoroquinolones are bactericidal in activity, act on subunit A of DNA gyrase (bacterial topoisomerase), and an enzyme that introduces negative super-twists into DNA and separates interlocked DNA molecules [1]. This leads to interference with DNA replication, segregation of bacterial chromosomes, transcription, and other cellular processes. Bacterial resistance to the newer fluoroquinolones occurs less frequently than to the older analogue, nalidixic acid [2]. Fluoroquinolones are highly effective against Gram positive and Gram negative bacteria both in vivo and in vitro with few of the problems of their predecessors [3]. The spectra of activity of the fluoroquinolones against these organisms appear comparable; however, differences emerge against other microorganisms, such as Chlamydia trachomatis, Mycobacterium species and Mycoplasma pneumoniae [4]. Ofloxacin is a synthetic chemotherapeutic antibiotic of the fluoroquinolone drug class considered to be a second-generation fluoroquinolones [5,6], with a broad spectrum of activity against gram-positive and gram-negative bacteria [7] with poor activity against anaerobes (4). Its chemical (IUPAC) name is (RS)-7-fluoro- 2-methyl- 6-(4-methylpiperazin1-yl)- $\quad$ 10-oxo-4-oxa-1-azatricyclo[7.3.1.05,13]trideca-5(13),6,8,11tetraene-11-carboxylic acid (Figure 1) [8]. It is a bactericidal and DNA gyrase inhibitor widely prescribed in acute and chronic lower respiratory tract infections and infections of ear and nose [9]. It functions by inhibiting DNA gyrase, a type II topoisomerase, and topoisomerase IV [10]. It is indicated for the treatment of adults with mild to moderate infections triggered by susceptible strains of the designated microorganisms in the infections like acute uncomplicated cystitis, bronchitis, chronic prostatitis, complicated UTIs, corneal ulcers, diabetic foot ulcer, GI infections, lower RTIs, meningococal infections, opthalmic infections, otitis externa, otitis media, pelvic inflammatory disease, pneumonia, prostatitis, pulmonary infection, septicaemia, sexually transmitted infections, skin and soft tissue infections, travelers diarrhoea, uncomplicated genital chlamydial infection, non-gonococcal urethritis, urinary tract infection, and can also be given in adjunctive therapy as an alternative drug of choice in conjuctivitis, osteomyelitis, skin infections, soft tissue infections. Oral absorption of Ofloxacin is found to be $100 \%$. Volume of distribution is found to be $1-2.5 \mathrm{~L} / \mathrm{kg}$ and plasma protein binding is $20-25 \%$ and metabolism is reported hepatic. Renal Excretion accounts for $80 \%$ and plasma half-life is $4.9 \mathrm{~h}-6.9 \mathrm{~h}$. The severe adverse effects of Ofloxacin include Sinus tachycardia, Hallucinations, Hallucinations, Stevens johnson syndrome, Stevens johnson syndrome, Seizures, Tendon rupture. Ofloxacin is also considered to be contraindicated within the pediatric population, pregnancy, nursing mothers, and patients with psychiatric illnesses and in patients with epilepsy or other seizure disorders. Spectrophotometry is characterized by its speed<smiles>CC1COc2c(N3CCN(C)CC3)c(F)cc3c(=O)c(C(=O)O)cn1c23</smiles>

Figure 1: Chemical structure of OFX.

*Corresponding author: Naveed S, Faculty of Pharmacy, Jinnah University for Women, Karachi, Pakistan, Tel: 00923002621917; E-mail: safila117@yahoo.com

Received March 07, 2016; Accepted April 05, 2016; Published April 12, 2016

Citation: Naveed S, Alam T, Hameed A, Sharif N (2016) UV Spectrophotometric Method for Estimation of Ofloxacin in Tablet Dosage Form and Comparative Study of its Two Brands. J Bioequiv Availab 8: 125-127. doi:10.4172/jbb.1000281

Copyright: (c) 2016 Naveed S, et al. This is an open-access article distributed under the terms of the Creative Commons Attribution License, which permits unrestricted use, distribution, and reproduction in any medium, provided the original author and source are credited. 
and simplicity, accuracy and inexpensive instrument needed, and hence it is an important alternative to other analytical methods, with clear advantages in terms of cost of analysis. A simple and sensitive spectrophotometric method for the determination of Ofloxacin (OFX) in pharmaceuticals is the measurement of absorbance of OFX in $0.1 \mathrm{M}$ $\mathrm{HCl}$ at $293 \mathrm{~nm}$ [11]. Our research group has performed comparative analysis of different brands available in the market which is very useful for health professionals [12-20].

\section{Experimental}

\section{Assay}

For the measurement of spectra UV visible 1601 Shimadzu double beam spectrophotometer was used. $0.1 \mathrm{M} \mathrm{HCl}$ was used as solvent.

\section{Material and reagents}

Pyrex glass wares were used which includes measuring cylinder, volumetric flask and pipette, mortar and pestle, weighing machine. For initially washing of glass wares we use chromic acid afterward we use water and finally rinsed with double distilled water (freshly prepared) and the tablets of different brands of Ofloxacin.

\section{Wavelength selection}

$10 \mathrm{mcg}$ solutions were prepared accurately and which was scanned between $200 \mathrm{~nm}-400 \mathrm{~nm}$ wavelength region. Maximum absorption was observed at $293 \mathrm{~nm}$ which was taken as lamda max.

\section{Standard stock solution}

$100 \mathrm{ml}$ solution was prepared by dissolving $10 \mathrm{mg}$ of Ofloxacin and absorbance was taken at its lamda-max after making its $10 \mathrm{mcg}$ dilution.

\section{Sample preparation}

From different medical store located in Karachi, two brands were purchased. Each brand was drawn from one marketed batch and contained $200 \mathrm{mg}$ per tablet.

Each brand was given a serial number for identification and average weight of tablet was taken and powder containing $200 \mathrm{mg}$ of Ofloxacin was drawn from each brand and transferred in $50 \mathrm{ml}$ of water and dissolved. After dissolving drug volume was makeup to $200 \mathrm{ml}$ with water. Absorbance was taken at its lamda-max after making its $10 \mathrm{mcg}$ dilution

\section{Procedure}

By preparing standard and sample solution having strength of $10 \mathrm{mcg}$ were made. Absorbance was taken by using $1 \mathrm{~cm}$ cell at maximum wavelength $293 \mathrm{~nm}$. By applying formula quantity of Ofloxacin (mg) present in each unit dosage form was calculated.

\begin{tabular}{|l|l|l|l|l|l|}
\hline Drug & Brands & Manufacturer & $\begin{array}{l}\text { Average weight } \\
\text { of tablets } \mathbf{( g m )}\end{array}$ & $\begin{array}{l}\text { Absorbance at } \mathbf{2 9 3} \mathbf{~ n m} \\
\text { Sample }\end{array}$ & Standard \\
\hline Drug A & Arloxin & Pakistan PP & 0.49428 & 0.980 & 0.980 \\
\hline Drug B & Ofloshine & Sunshine P & 0.34485 & 0.941 & 0.977 \\
\hline
\end{tabular}

Table 1: Absorbance of different brands of Ofloxacin.

\begin{tabular}{|c|c|}
\hline Brands & Percentage of assay \\
\hline Drug A & $100 \%$ \\
\hline Drug B & $96.31 \%$ \\
\hline
\end{tabular}

Table 2: Percentage assay of different brands of Ofloxacin.

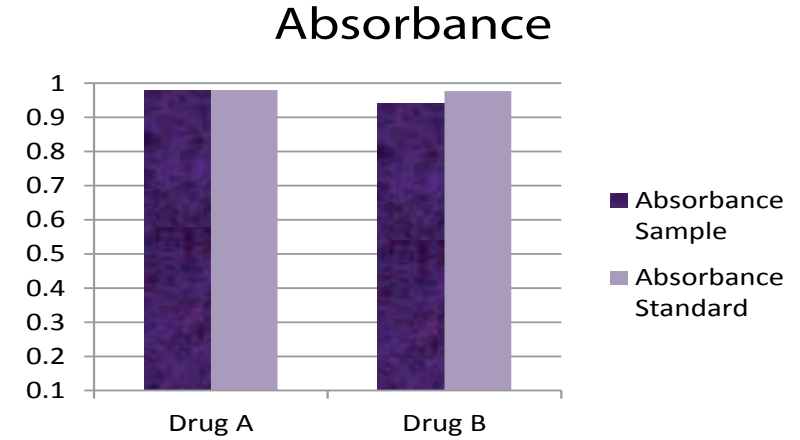

Figure 2: Absorbance of Ofloxacin.

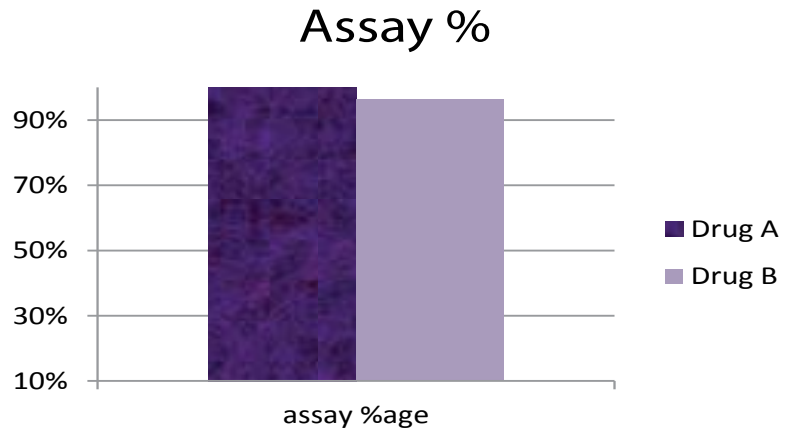

Figure 3: Percentage assay of Ofloxacin.

\section{Result and Discussion}

The aim of the study was to carry out the pharmaceutical assay on two different brands of Ofloxacin $(200 \mathrm{mg})$ tablets. Results are given in Tables 1 and 2, both the drugs shows results within the range. Pharmaceutical assay of Ofloxacin was carried out on different brands using spectrophotometer Figures 2 and 3. Table 1 shows brand name, manufacturer, average weight and absorbance of $10 \mathrm{mcg}$ solution in $0.1 \mathrm{M} \mathrm{HCl}$ at $293 \mathrm{~nm}$ against the solvent blank. \% assay of different brands is shown in Table 2. This proposed method for assay of commercially available Ofloxacin tablet formulation is very simple, economical, accurate, least time consuming and rapid. It can be used for routine QC quality control analysis in the API, and tablet formulation. Our results reveal that both brands of Ofloxacin are bioequivalent and are within the official range. Arloxin shows a percent assay of $100 \%$ while Ofloshine shows low value for percentage assay that is $96.31 \%$.

\section{Conclusion}

It is concluded that both available brands are equivalent as having $\%$ assay approximately equal hence can be used for the treatment of bacterial infection.

\section{References}

1. Goudah A, Mouneir SM, Shim JH, Abd El-Aty AM (2006) Influence of endotoxin induced fever on the pharmacokinetics of intramuscularly administered cefepime in rabbits: $\mathrm{J}$ Vet Sci 7: 151-155.

2. Baruah H, Roy DC, Roy RK, Khonikor HN (2004) Pharmacokinetics, tissue residue and plasma protein binding of ofloxacin in goats. J Vet Sci 5: 97-101.

3. Marier JF, Ducharme MP, DiMarco M, Di Spirito M, Morelli G, et al. (2006) Two open-label, randomized, crossover studies assessing the bioequivalence 
Citation: Naveed S, Alam T, Hameed A, Sharif N (2016) UV Spectrophotometric Method for Estimation of Ofloxacin in Tablet Dosage Form and Comparative Study of its Two Brands. J Bioequiv Availab 8: 125-127. doi:10.4172/jbb.1000281

of ofloxacin administered as immediate-and extended-release formulations in healthy subjects. Clin Ther 28: 2070-2080.

4. Liang $\mathrm{H}$, Kays MB, Sowinski KM (2002) Separation of levofloxacin, ciprofloxacin, gatifloxacin, moxifloxacin, trovafloxacin and cinoxacin by high-performance liquid chromatography: application to levofloxacin determination in human plasma. J Chromatogr B Analyt Technol Biomed Life Sci 772: 53-63.

5. Nelson JM, Chiller TM, Powers JH, Angulo FJ (2007) Fluoroquinolone-resistant Campylobacter species and the withdrawal of fluoroquinolones from use in poultry: a public health success story. Clin Infect Dis 44: 977-980.

6. Kawahara S (1998) Chemotherapeutic agents under study. Nihon Rinsho 56: 3096-3099.

7. Sato K, Matsuura Y, Inoue M, Une T, Osada Y, et al. (1982) In vitro and in vivo activity of DL-8280, a new oxazine derivative. Antimicrob Agents Chemother 22: $548-553$

8. Sultana N, Arayne MS, Yasmeen N (2007) In vitro availability of ofloxacin in presence of metals essential to human body. Pak J Pharm Sci 20: 42-47.

9. Sweetman SC (Eds) (2007), Martindale: The Complete Drug Reference London: Pharmaceutical Press. Electronic version, $35^{\text {th }}$ (Edn) 41: 1321.

10. Drlica K, Zhao X (1997) DNA gyrase, topoisomerase IV, and the 4-quinolones. Microbiol Mol Biol Rev 61: 377-392.

11. Vinay KB, Revanasiddappa HD; Divya MR; Rajendraprasad N (2009)
Spectrophotometric determination of ofloxacin in pharmaceuticals and human urine. Eclet Quím 34.

12. Dilshad H, Naveed S, Rafiq A (2014) Comparitive study of four different brands of acetaminophen available in Karachi. WJPS 2: 586-590.

13. Dilshad H, Naveed S, Waheed N (2014) Comparitive study of four different brands of captopril available in Karachi. Int Res J Pharm 5: 374-377.

14. Naveed S, Qamar F (2014) Comparative study of different Brands of Alprazolam. Global Journal of Medical Research 14: 25-28.

15. Naveed S, Waheed N (2014) Comparative study of three different brands of doxycycline capsules available in Karachi open access library journal 1: 1-7.

16. Naveed S, Dilshad H, Jaweed L (2014) Comparative study of four different brands of ranitidine available in Karachi. Mod Chem appl 2:125.

17. Naveed S and Qamar F (2014) Comparative study of metronidazole formulations. DHR International Journal of Pharmaceutical Sciences (DHRIJPS) 5: 111-116

18. Naveed S, Dilshad H, Aziz S (2014) Comparitive study of different brands of Atenolol available in Karachi. MJPMS 3:17-19.

19. Naveed S, Qamar F (2014) Comparative Analysis of different brands of Diclofenac Sodium. MJPMS 3: 38-40

20. Dilshad H, Naveed S, Ahad S (2014) Comparitive study of different brands of Tizanidine. IJPRDD 1: 1-8. 